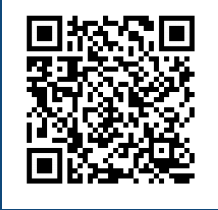

Keywords:

Cerejeira-da-Amazônia

Vigor of forest seeds

Quality of forest seedlings

Davi da Silvala ${ }^{1 a}$ Carlos André Stuepp ${ }^{2 a+}$, Ivar Wendling ${ }^{3 a}$, Cristiane Helm ${ }^{3 b}$, Alessandro Camargo Angelo'b

\title{
INFLUENCE OF SEED STORAGE CONDITIONS ON QUALITY OF Torresea acreana SEEDLINGS
}

SILVA, D.; STUEPP, C. A.; WENDLING, I.; HELM, C.; ANGELO, A. C. E Influence of seed storage conditions on quality of Torresea acreana seedlings. CERNE, v. 25, n. I, p. 60-67, 2019.

\section{HIGHLIGHTS}

There is a shortage of studies seeking to correlate the quality of seedlings with the effects generated by the storage of seeds of forest species.

Seed storage proved to be a negative factor for the emergence and vigor of Torresea acreana seedlings.

The vigor of the seeds is a preponderant factor to increase the morphological quality of the seedlings.

\section{ABSTRACT}

Historic:

Received 31/10/2018

Accepted 04/0 I/2019

Correspondence: castuepp@uepg.br
The plant vigor defined in the laboratory may not indicate the final quality of seedlings produced under nursery conditions, or even their survival in plantations. So, we evaluated the influence of the storage conditions of Torresea acreana seeds on its emergence, as well as, on the morphological quality of produced seedlings. Seeds were collected in October/20II, packed, transported, conditioned in closed glas pots and stored in three environments for a period of 462 days. The treatments consisted of seedlings produced from seeds: I - without storage (control), 2 - stored in a dry chamber, 3 - stored in a humid chamber, and 4 - stored in an uncontrolled environment (laboratory). Sowing was performed in $50 \mathrm{~cm}^{3}$ plastic tubes filled with decomposed pine bark and coconut fiber $(50 / 50 \mathrm{v} / \mathrm{v})$ which were packed in a glasshouse. The study analyzed the percentage of emergence, mean seedlings emergence time, stem diameter, total height, ratio between total height and stem diameter, shoot length, mean root length, total dry biomass, root dry biomass, shoot dry biomass, and Dickson quality index. Seed storage proved to be a negative factor for the emergence and vigor of T. acreana seedlings. The vigor of the seeds is a preponderant factor to increase the morphological quality of the seedlings. 


\section{INTRODUCTION}

The demand for native forest seedlings is growing, because of legal issues, mainly for restoration of legal reserves and recovery of degraded ecosystems (Brazil, 2012; Wielewicki et al., 2006; Ribeiro-Oliveira and Ranal, 2014). Faced with this situation, the need for large-scale production of quality seedlings with reduced costs is increasing.

Fortheproduction of qualityseedlings, itisnecessary to store large quantities of seeds for long periods of time. This fact becomes even more important when working with species that present seasonality in fruit production, that is, a year of good production is usually succeeded by a year of low production (Oliveira et al., 2017), in general, influenced by the climatic variation inherent in the region of origin (Marques et al., 2004).

The demand for quality seedlings comes from the need to avoid losses from mortality and low growth after planting, together with the need to reduce the cultural treatments applied to the plants resulting in a competition reduction with invasive plants (Figueiredo et al., 20II; Dumroese et al., 20II). The quality of a seedling can be evaluated through the measurement of morphological characters such as shoot height, stem diameter, development of the root system, stem lignification, and genetic material (Figueiredo et al., 20 I I; Pezzutti et al., 20II).

In order to avoid seed shortage, storage may be an excellent alternative in order to maintain or minimize the loss of physiological quality until sowing (Vijay et al., 2015). It may also generate new perspectives for species such as Torresea acreana Ducke (Fabaceae) as a climax species with a natural occurrence in South America (Carvalho, 2007). It has attractive characteristics for timber industry, and has already been identified among the 20 most traded native species in the state of Mato Grosso, Brazil (Ribeiro et al., 2016).

In order to ensure seed quality during storage, it is necessary to know the physiological quality of these seeds, which is expressed in practice by the production of vigorous seedlings with high potential for survival under field conditions (Oliveira, 2012). In addition, vigor also affects the optimization of the seedling production system, with greater speed and uniformity in seedling emergence and less time in a nursery, which is reflected in the costs of production. However, information generated on seeds storage, most of the times, is not associated with the process of seedlings production in a nursery, and the vigor defined in the laboratory does not represent the final quality of these seedlings, neither the survival in field conditions.

Thus, based on the importance of seed storage on viability of seedlings production of forest species, we evaluated the influence of storage conditions of T. acreana seeds on its emergence and, on the morphological quality of produced seedlings.

\section{MATERIALS AND METHODS}

Seeds were collected in October/20II in a seed production area located on experimental field of EMPAER, São José dos Quatro Marcos, Mato Grosso,

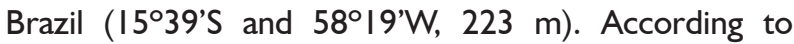
the Köppen classification, the climate of the region is tropical, Aw type, average temperature of the coldest month above $18^{\circ} \mathrm{C}$, rainy season in the summer, from November to April, and clear dry season in winter. The seed production area consisted of a set of 42 plants, from which 12 productive trees were selected located in the center of the plot.

After collection, the seeds were packed in plastic containers, placed in cardboard boxes, and sent to the Seed Laboratory of the Forest Engineering Department of the Federal University of Paraná. For the initial characterization of the lot, the number of seeds per kilogram (seeds $\mathrm{Kg}^{-1}$ ), the dimensions of the major and minor axes per seed, purity (\%) and moisture content (\%) were evaluated following the methodologies established by the analysis rules for seeds (Brasil, 2009).

The seeds were stored in sealed containers in three environments: I - dry chamber at $20 \pm 2{ }^{\circ} \mathrm{C}$ and $60 \%$ relative humidity, II - humid chamber at $5 \pm 2{ }^{\circ} \mathrm{C}$ and $80 \%$ relative humidity, and III - under uncontrolled conditions in a laboratory environment. After 462 days of storage, seed moisture content (wet basis) was determined in 5 replicates of 10 seeds, by placing them in an oven at $105 \pm 3{ }^{\circ} \mathrm{C}$ for a period of 24 hours under forced air circulation (Brasil, 2009).

Before seedlings quality evaluation the seeds were disinfested by immersion for 3 minutes in $1 \%$ sodium hypochlorite solution $(\mathrm{NaClO})$. For seedlings morphological quality evaluation and seed vigor, four treatments were used, corresponding to the seeds storage environments: I - Seedlings produced from seeds without storage (control), 2 - Seedlings produced from seeds stored in a dry chamber for 462 days, 3 - Seedlings produced from seeds stored 
in a humid chamber for 462 days, and 4 - Seedlings produced from seeds stored in an uncontrolled environment (laboratory) for 462 days.

For seedlings production we used $50 \mathrm{~cm}^{3}$ pastic tubes filled with substrate made with decomposed pine bark and coconut fiber $(50 / 50 \mathrm{v} / \mathrm{v})$, with the addition of $1.3 \mathrm{~kg} \mathrm{~m}^{-3}$ of Osmocote ${ }^{\circledR}$ 18-5-9 Mini Prill (5M). One seed was manually placed in the center of the tube, then covered with a substrate layer, approximately twice the thickness of the seed, or $2 \mathrm{~cm}$. After sowing, the tubes were conditioned in a glasshouse (three daily irrigations of 10 minutes with a flow rate of $\left.144 \mathrm{~L}_{\text {hour }}{ }^{-1}\right)$, where they remained for 90 days.

Emergence evaluation and morphological description of seedlings were performed at intervals of two days, until seedlings presented the first differentiated leaves (leaf primordia) (Figure I). The percentage of seedlings emergence (PSE) and mean seedlings emergence time (MSET) were evaluated simultaneously. For the evaluation, seedlings that emerged with MSET $<15$ days were considered vigorous and non-vigorous seedlings with MSET $\geq 15$ days.

At 90 days after the beginning of the experiment, stem diameter $(S D)$, total height $(H)$, ratio between total height and stem diameter $(H / S D)$, shoot length $(S L)$, root length (RL), total dry biomass (TDB), root dry biomass (RDB), and shoot dry biomass (SDB) were evaluated. Morphological indexes were also calculated: ratio of total height and stem diameter $(\mathrm{H} /$ $\mathrm{SD}$ ) and Dickson quality index (DQI) (Dickson et al., 1960). The Dickson quality index was determined using the following formula I, Where: TDB Total dry biomass ( $\mathrm{g}$ ); H/SD - Ratio between total height $(\mathrm{H})$ and stem diameter (SD); SDB - Shoot dry biomass (g); RDB - Root dry biomass (g).

$$
D Q I=T D B /(H / S D+S D B / R D B)
$$

Destructive evalulations were made in ten plants per experimental unit and consisted of the shoot and root dry biomass ( 24 hours in an oven at $105 \pm 2{ }^{\circ} \mathrm{C}$ until constant weight, obtained using an analytical balance of 0.001 gram precision).

The experiment to evaluate PSE and MSET was set in a completely randomized design with five replicates of 100 seeds per experimental unit. For morphological seedlings quality evaluation, a completely randomized design was used in a $4 \times 2$ factorial scheme, of four storage environments and greater or less seedling emergence vigor, with five replications of 10 seedlings per experimental unit. Variances of the treatments were evaluated for homogeneity by Bartlett's test; variables with significant differences by the F-test had their means compared by Tukey's test at $5 \%$ probability level. To verify the mean seedlings emergence influence time on the morphological variables, Pearson correlation analysis $(p<0.01$ and $p<0.05)$ was applied.

\section{RESULTS}

The seeds showed, on average,
2395.77 units $\mathrm{Kg}^{-1}$ with dimensions of I4.I $\mathrm{mm}$ (major axis) and $9.3 \mathrm{~mm}$ (minor axis); the sample had $97.25 \%$ purity. Seeds moisture content was $9.84 \%$ for seeds without storage (control) (TI), $10.22 \%$ for T2, $10.39 \%$ for T3, and $10.44 \%$ for T4.

Percentage of seedlings emergence was significantly higher in non-stored seeds (control) with $89.40 \%$. In general, the seeds submitted to storage for 462 days presented percentage of seedlings emergence below $50 \%$, with a slight reduction as a function of the storage environment, which was better when stored in a dry chamber (Table I).

TABLE I Percentage of seedlings emergence (PSE) and mean seedlings emergence time (MSET) in Torresea acreana seeds as a function of storage conditions.

\begin{tabular}{ccc}
\hline Treatments & $\begin{array}{c}\text { PSE } \\
(\%)\end{array}$ & $\begin{array}{c}\text { MSET } \\
\text { (days) }\end{array}$ \\
\hline TI & $89.40 \mathrm{a}$ & $24.77 \mathrm{c}$ \\
T2 & $45.60 \mathrm{~b}$ & $29.55 \mathrm{~b}$ \\
T3 & $42.60 \mathrm{bc}$ & $30.90 \mathrm{ab}$ \\
T4 & $41.80 \mathrm{c}$ & $32.01 \mathrm{a}$ \\
Means & 54.85 & 29.31 \\
Coefficient of variation & 3.66 & 3.02 \\
\hline
\end{tabular}

Means followed by the same letter in the column do not differ from each other, according to Tukey's test at $5 \%$ probability level. TI - Seeds without storage (control); T2 - Seeds stored in dry chamber for 462 days; T3 - Seeds stored in a humid chamber for 462 days; T4 - Seeds stored in an uncontrolled environment (laboratory) for 462 days.

From the previous evaluations, we verified that $T$. acreana seeds presented hypogeal germination, with epicotyl emission 24 hours after emergence (data not shown). Mean seedlings emergence time was significantly higher for seeds stored under uncontrolled conditions (32.0I days) and in humid chamber (30.90 days). There was a significant reduction in the vigor of stored seeds, while non-stored seeds presented the lowest mean seedlings emergence time of 24.77 days. The process of seed germination ended at 32 days after germination, identified by the main and secondary root differentiation and the the first leaf primordia (Table I) (Figure I). 


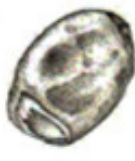

1

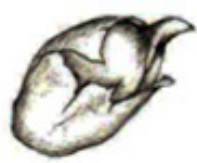

2

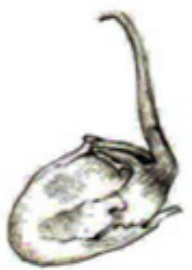

3

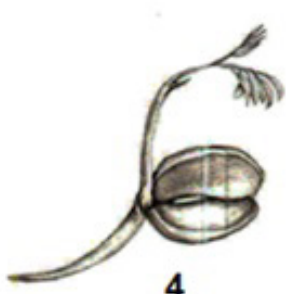

4

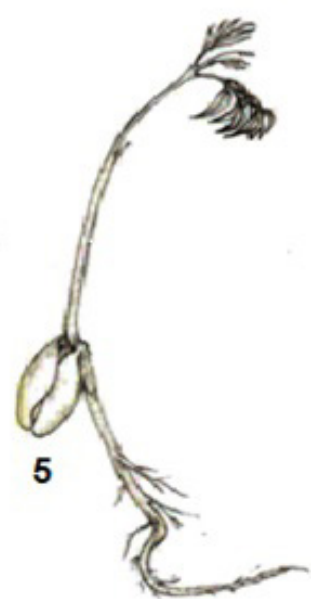

FIGURE I Morphological aspects of the germination and emergence of Torresea acreana seeds. I - Scarified seed at the time of sowing; 2 - Seed with epicotyl emergence; 3 - Seed with differentiated epicotyl without the emission of the first leaf primordia; 4 - Seed in the final stage of germination with main root and first leaf primordia emergence; 5 - Seedling in the final emergence stage with main and secondary roots and first leaves emergence.

$\begin{array}{clcc}\text { Total height }(\mathrm{H}) & \text { and shoot } \\ \text { length }(\mathrm{SL}) & \text { of seedlings produced from }\end{array}$ non-stored and vigorous seeds were significantly higher, with $42.91 \mathrm{~cm}$ and $31.10 \mathrm{~cm}$, respectively. Only in the control treatment significant differences were observed between vigorous and non-vigorous plants in both variables. The lowest values verified for these variables were identified in seeds stored in an uncontrolled environment (Table 2).

For root dry biomass (RDB), the highest values were observed in seedlings produced by non-stored seeds (control), without significant differences between vigorous and non-vigorous seeds, with 4.46 and 4.35 grams, respectively. The lowest values verified for this variable were identified in seeds stored in an uncontrolled environment (laboratory), with 2.86 grams for vigorous seeds, significantly higher than for non-vigorous seeds (Table 2).

Stem diameter (SD) showed the highest values in treatments I, 2, and 3, with 2.47, 2.34, and $2.35 \mathrm{~mm}$, respectively. Similarly, the Dickson Quality Index (DQI) showed the lowest values for seeds stored in an uncontrolled environment (control treatment) (Table 3).

The ratio between total height and stem diameter $(H / S D)$ was significantly higher in seedlings produced from non-stored seeds (control treatment). Root length did not show statistical differences between treatments I, 2, and 3, and only differed from seeds stored under uncontrolled conditions. Total dry biomass (TDB) and shoot dry biomass (SDB) showed similar results, with the best values observed in seedlings produced from nonstored seeds, with 9.08 and 4.67 , respectively, which is higher than for the other treatments (Table 3).
TABLE 2 Total height $(H)$, shoot length (SL), and root dry biomass (RDB) of $T$. acreana seeds at 90 days as a function of seed storage conditions and seedlings emergence vigor.

\begin{tabular}{|c|c|c|c|c|c|c|}
\hline \multirow{2}{*}{$\begin{array}{c}\text { Storage } \\
\text { conditions }\end{array}$} & \multicolumn{2}{|c|}{$\mathrm{H}(\mathrm{cm})$} & \multicolumn{2}{|c|}{$\mathrm{SL}(\mathrm{cm})$} & \multicolumn{2}{|c|}{ RDB (g) } \\
\hline & V & NV & V & NV & V & NV \\
\hline TI & $42.91 \mathrm{aA}$ & $37.46 \mathrm{aB}$ & $31.10 \mathrm{aA}$ & $25.91 \mathrm{aB}$ & $4.46 \mathrm{aA}$ & $4.35 \mathrm{aA}$ \\
\hline $\mathrm{T} 2$ & $28.7 \mathrm{I} \mathrm{bA}$ & $27.77 \mathrm{bA}$ & $16.81 \mathrm{bA}$ & $16.28 \mathrm{bA}$ & $3.49 \mathrm{bA}$ & $3.45 \mathrm{bA}$ \\
\hline T3 & $28.80 \mathrm{bA}$ & $28.07 \mathrm{bA}$ & $16.76 \mathrm{bA}$ & $15.99 \mathrm{bcA}$ & $3.52 \mathrm{bA}$ & $3.43 \mathrm{bA}$ \\
\hline $\mathrm{T} 4$ & $24.54 \mathrm{cA}$ & $23.87 \mathrm{cA}$ & $13.27 \mathrm{cA}$ & $12.86 \mathrm{cA}$ & $2.86 \mathrm{cA}$ & $2.44 \mathrm{cB}$ \\
\hline Means & \multicolumn{2}{|c|}{30.28} & \multicolumn{2}{|c|}{18.62} & \multicolumn{2}{|c|}{3.50} \\
\hline $\begin{array}{c}\text { Coefficient } \\
\text { of variation } \\
(\%)\end{array}$ & \multicolumn{2}{|c|}{7.04} & \multicolumn{2}{|c|}{10.31} & \multicolumn{2}{|c|}{4.02} \\
\hline
\end{tabular}

Means followed by the same lowercase letter in the column and uppercase letter in the row do not differ from each other, according to Tukey's test at 5\% probability level. V - Seedlings classified as vigorous; NV - Seedlings classified as non-vigorous; TI - Seeds without storage (control); T2 - Seeds stored in dry chamber for 462 days; T3- Seeds stored in a humid chamber for 462 days; T4 - Seeds stored in an uncontrolled environment (laboratory) for 462 days.

With the exception of the ratio $\mathrm{H} / \mathrm{SD}$, all evaluated variables were significantly influenced by seedlings emergence vigor, with the best results associated with more vigorous seeds (Table 4).

The correlation analysis showed a significant influence of mean seedlings emergence time on the different evaluated variables, except for TDB for vigorous and non-vigorous seeds, and DQI for vigorous seeds. In addition, all other variables showed a negative correlation (Table 5).

\section{DISCUSSION}

The average size of $T$. acreana
seeds was lower than those verified by Gunn (198I), who describes the seeds as slightly 
elongated, between $12.55 \mathrm{~mm}$ to $17.50 \mathrm{~mm}$, and width ranging from $8.33 \mathrm{~mm}$ to $11.50 \mathrm{~mm}$. The number of seeds $\mathrm{Kg}^{-1}$ (2395.77) was higher than that reported in the literature, with 800 seeds $\mathrm{Kg}^{-1}$ (Carvalho, 2007).

TABLE 3 Stem diameter (SD), ratio between height and stem diameter $(\mathrm{H} / \mathrm{SD})$, Dickson quality index (DQI), root length (RL), total dry biomass (TDB), and shoot dry biomass (SDB) in T. acreana seedlings at 90 days as a function of seeds storage conditions.

\begin{tabular}{|c|c|c|c|c|c|c|}
\hline \multirow{2}{*}{$\begin{array}{c}\text { Storage } \\
\text { conditions }\end{array}$} & \multirow{2}{*}{$\begin{array}{c}\text { SD } \\
(\mathrm{mm})\end{array}$} & \multirow{2}{*}{$\mathrm{H} / \mathrm{SD}$} & \multirow{2}{*}{ DQI } & \multirow{2}{*}{$\begin{array}{l}\mathrm{RL} \\
(\mathrm{cm})\end{array}$} & TDB & SDB \\
\hline & & & & & \multicolumn{2}{|c|}{------ (g) ------ } \\
\hline TI & $2.47 \mathrm{a}$ & $16.21 \mathrm{a}$ & $0.52 \mathrm{a}$ & $11.68 \mathrm{ab}$ & $9.08 \mathrm{a}$ & $4.67 \mathrm{a}$ \\
\hline T2 & $2.34 \mathrm{a}$ & $12.04 \mathrm{~b}$ & $0.50 \mathrm{a}$ & $11.69 \mathrm{a}$ & $6.52 \mathrm{~b}$ & $3.36 \mathrm{~b}$ \\
\hline T3 & $2.35 \mathrm{a}$ & $12.10 \mathrm{~b}$ & $0.5 \mathrm{I} \mathrm{a}$ & $11.86 \mathrm{a}$ & $6.68 \mathrm{~b}$ & $3.34 \mathrm{~b}$ \\
\hline T4 & $2.09 \mathrm{~b}$ & II.54 b & $0.43 \mathrm{~b}$ & II.II b & $5.43 c$ & $2.76 \mathrm{c}$ \\
\hline Means & 2.31 & 12.97 & 0.49 & 11.59 & 6.93 & 3.53 \\
\hline Coefficient & & & & & & \\
\hline $\begin{array}{c}\text { of variation } \\
(\%)\end{array}$ & 5.74 & 5.14 & 7.57 & 4.09 & 5.75 & 3.67 \\
\hline
\end{tabular}

Means followed by the same letter in the column do not differ from each other according to Tukey's test at $5 \%$ probability level. TI - Seeds without storage (control); T2 - Seeds stored in dry chamber for 462 days; T3- Seeds stored in a humid chamber for 462 days; T4 - Seeds stored in an uncontrolled environment (laboratory) for 462 days.

TABLE 4 Stem diameter (SD), total height $(H)$, ratio between total height and stem diameter $(\mathrm{H} / \mathrm{SD})$, Dickson quality index (DQI), total dry biomass (TDB), root dry biomass $(\mathrm{RDB})$, shoot dry biomass (SDB), root length (RL), and shoot length (SL) in Torresea acreana seedlings at 90 days as a function of seedlings emergence vigor.

\begin{tabular}{|c|c|c|c|c|c|c|c|c|c|}
\hline Seedling & SD & $\mathrm{H}$ & $\mathrm{H} / \mathrm{SD}$ & DQI & TDB & RDB & SDB & RL & SL \\
\hline emergence & $(\mathrm{mm})$ & $(\mathrm{cm})$ & - & - & -----. & $---(\mathrm{g})--$ & -------- & ---- (cr & m) ---- \\
\hline Vigorous & $2.39 a$ & $31.26 a$ & $12.92 \mathrm{a}$ & $0.5 \mathrm{Ia}$ & $7.15 \mathrm{a}$ & $3.58 \mathrm{a}$ & $3.63 a$ & $11.77 a$ & $19.48 \mathrm{a}$ \\
\hline $\begin{array}{l}\text { Non- } \\
\text { vigorous }\end{array}$ & $2.24 \mathrm{~b}$ & $29.29 \mathrm{~b}$ & $13.03 a$ & $0.47 \mathrm{~b}$ & $6.70 \mathrm{~b}$ & $3.42 \mathrm{~b}$ & $3.43 \mathrm{~b}$ & $11.40 \mathrm{~b}$ & $17.76 \mathrm{~b}$ \\
\hline Means & 2.31 & 30.28 & 12.97 & 0.49 & 6.93 & 3.5 & 3.53 & 11.59 & 18.62 \\
\hline $\begin{array}{l}\text { Coefficient } \\
\text { of variation } \\
(\%)\end{array}$ & 5.74 & 7.04 & 5.14 & 7.57 & 5.75 & 4.02 & 3.67 & 4.09 & 10.31 \\
\hline
\end{tabular}

Means followed by the same letter in the column do not differ from each other, according to Tukey's test at $5 \%$ probability level..

TABLE 5 Correlation between the mean seedlings emergence time (MSET) and the morphological variables evaluated in T. acreana seedlings.

\begin{tabular}{ccc}
\hline Variables & Vigorous & Non-vigorous \\
\hline MSET X SD & $-0.63^{* *}$ & $-0.59^{* * *}$ \\
MSET X H & $-0.87^{* *}$ & $-0.94^{* *}$ \\
MSET X SL & $-0.91^{* *}$ & $-0.89^{* *}$ \\
MSET X RL & $-0.88^{* *}$ & $-0.94 * *$ \\
MSET X TDB & $-0.17 \mathrm{~ns}$ & $-0.32 \mathrm{~ns}$ \\
MSET X RDB & $-0.89 * *$ & $-0.90^{* *}$ \\
MSET X SSB & $-0.88^{* *}$ & $-0.86 * *$ \\
MSET X H/SD & $-0.91^{* *}$ & $-0.92^{* *}$ \\
MSET X DQI & $-0.40 \mathrm{~ns}$ & $-0.50^{*}$ \\
\hline
\end{tabular}

**, *; Significant at $5 \%$ and $1 \%$ probability, respectively; ns Not significant. $\mathrm{SD}$ - stem diameter; $\mathrm{H}$ - total height; $\mathrm{H} / \mathrm{SD}$ - ratio between total height and stem diameter; DQI - Dickson quality index; TDB - total dry biomass; RDB - root dry biomass; SDB - shoot dry biomass; RL - root length; SL - shoot length.
The storage conditions of seeds after the process of collecting and processing are critical to maintain their physiologic conditions for longer periods, when they reach equilibrium moisture. The temperature and humidity of the seeds storage environment are two preponderant variables to determine the prolonged physiological quality in forest seeds (Motlagh and Shaban, 2014). Thus, the best storage condition of orthodox seeds, such as T. acreana, is an environment with low relative humidity and temperature, in which the embryo can maintain a lower metabolic activity (Zuchi et al., 2013; Walters, 2015). Despite this, the moisture content of the seeds did not change significantly after 462 days, regardless of storage conditions.

Germination percentage is one of the variables most used to indicate seed vigor (Mello et al., 20l3), and the variations verified in this study indicate a sensitivity in viability maintenance of $T$. acreana seeds when stored, mainly under uncontrolled conditions. The highest percentage of seedlings emergence (PSE) in non-stored seeds $(89.40 \%)$ can be explained by the physiological quality of these seeds, collected at the point of physiological maturation.

After the seeds physiological maturation, the process to deteriorate gradually begins, resulting in the consequent reduction in germination potential (Kapoor etal.,201 I;Girardietal., 2017). This deterioration is favored by the humidity of the environment, which depends on the air relative humidity, i.e, higher humidity increases the moisture content of the seeds, which leades to greater deterioration of the seeds (Shaban et al., 20I3). This is even more evident when analyzing the low PSE in seeds submitted to storage for 462 days, which was below $50 \%$ regardless of the treatment (Table I). Despite the low PSE after storage, it is possible to observe slight superiority of seeds stored in dry $(45.60 \%)$ and humid chamber $(42.60 \%)$ compared to storage in an uncontrolled environment (4I.80\%) (Table I). This fact evidences some of the main physiological symptoms related to seed deterioration, such as reduction in germination percentage and seedlings vigor (Donadon et al., 20I5), which initially comes from the disruption of the membrane system from the attack of free radicals to its constituent cells (Bewley et al., 2013). In addition, the loss of seeds physiological quality as a consequence of storage directly reflects their viability.

Similar to PSE, mean seedlings emergence time (MSET) was significantly influenced by seeds storage. The increase in MSET has direct implications on the seedlings quality, since the initial seeds vigor is lost, which 
is desirable for seedlings production of forest species. This reduction in vigor is a consequence of storage, in which seeds quality cannot be improved; it can only be preserved when placed in conditions favorable to this preservation, such as humidity and temperature, thus reducing the seeds metabolism and consequently the attack of pathogenic microorganisms (Zuchi et al., 20।3).

Total height $(\mathrm{H})$ and shoot length $(\mathrm{SL})$ are two similar variables, where the first is represented by the sum of the root and shoot portion and the second represented only by the shoot portion. Both variables were significantly influenced by the seeds non-storage (Table 2), a consequence of vigor reduction of these seeds, thus corroborating the results expressed for emergence and mean seedlings emergence time (Table I). Only for non-stored seeds significant differences could be observed between vigorous and non-vigorous seeds, which reinforces the hypothesis of the loss of vigor associated with storage.

In contrast, seeds vigor did not influence root dry biomass (RDB) after 90 days, which is possibly related to the physical limitation imposed by the container, since, from the filling of the root system, the trend is stagnation in its development, particularly regarding the number of rootlets that influence the absorption of nutrients and reflect the root dry biomass (Brachtvogel and Contro Malavasi, 2010).

Stem diameter is a key variable to assess the potential for survival and growth after planting forest species (Da Silva et al., 20I2); there is evidence that, within the same species, plants with increased stem diameter tend to have greater growth capacity (Souza et al., 2006). Dickson Quality Index (DQI) and root length (RL), stem diameter (SD) were only smaller when the seeds were stored under uncontrolled conditions (Table 3).

Similarly, the ratio between total height and stem diameter $(H / S D)$ may be representative, as it denotes or not a proportional growth of the seedlings (Kratz et al., 2016; Stuepp et al., 2016). In addition to being a good reference parameter for reserves accumulation, it may represent a greater resistance and fixation of the seedlings to substrate (Artur et al., 2007). The H/SD is among the most used variables and has been proven in consolidated systems of forest seedlings production, and it can be an excellent indicator of the capacity for seedlings survival at field conditions, where, in general, plants with larger stem diameter and lower heights are considered of better quality when compared to those with high height and reduced stem diameter (Gomes et al., 2002).

Total dry biomass (TDB) and shot dry biomass (SDB) were influenced by seeds storage, with higher values in non-stored seeds (Table 3 ). In addition to the qualitative aspect of the seedlings, the SDB presents a direct relation with the photosynthetically active leaf surface, constituting a very important variable to determine the capacity for survival of the seedlings after planting (Bellote and Silva, 2000). Similarly, TDB represents an adequate conversion of solar energy to assimilated compounds, mainly carbohydrates, providing greater availability of these compounds after planting. This is reflected not only on the shoots but on the different plant organs, making it of fundamental importance in the evaluation of the efficiency and potential of growth in the field (Ataíde et al., 20I0).

Seeds vigor is a complex physiological characteristic essential to ensure rapid and uniform seedlings emergence under adverse environmental conditions and it depends basically on the resistance to the degenerative effects caused by storage (Ventura et al., 20I2). The effect of seeds vigor on seeds quality is evident when, with the exception of $H / S D$, all morphological variables evaluated showed a significant influence on seedlings emergence vigor (Table 4).

In practice, vigorous seeds have its physiological quality expressed by the production of vigorous seedlings with improved field survival (Oliveira, 2012). In this study, seeds vigor was determined by average germination time, i.e. seeds germinated in periods shorther than 15 days were considered vigorous and those that germinated in periods equal to or greater than 15 days were non-vigorous. The effect verified by the negative correlation between mean seedlings emergence time (MSET) and the different morphological variables explains the importance of seeds vigor on the final quality of $T$. acreana seedlings (Table 5 ). The lower the emergence time, or the faster this process occurs, better the final quality of produced seedlings.

The longevity of orthodox seeds is determined mainly by the storage environment with expected increase in shelf life with the reduction in temperature and relative humidity (Walters, 20I5). In general, the results presented in this study demonstrate the importance of seeds vigor for the production of $T$. acreana seedlings, even in prolonged periods of storage, mainly in relation to environmental humidity control. In this way, the use of this species in silvicultural systems can be extended from the ecological and economic point of view.

\section{CONCLUSION}

Under the conditions used in the experiment, seed storage proved to be a negative factor for the 
emergence and vigor of $T$. acreana seedlings, with a significant decrease during storage period. The vigor of the seeds is a preponderant factor to increase the morphological quality of the seedlings.

\section{REFERENCES}

ARTUR, A. G.; CRUZ, M. C. P. D. A.; FERREIRA, M. E.; BARRETTO, V. C. M.; YAGI, R. Esterco bovino e calagem para formação de mudas de guanandi. Pesquisa Agropecuária Brasileira, v. 42, n. 6, p. 843-850, 2007.

ATAÍDE, G.; CASTRO. R.; SANTANA R.; DIAS. B.; CORREIA A.; MENDES A. Efeito da densidade na bandeja sobre o crescimento de mudas de eucalipto. Revista Trópica: Ciências Agrárias e Biológicas, v. 4, n. 2, p. 2I-26, 2010.

BELLOTE, A. J. F.; SILVA, H. D. Técnicas de amostragem e avaliações nutricionais em plantios de Eucalyptus spp. In.: Gonçalves, J. L. M.; Benedetti, V. Nutrição e fertilização florestal. IPEF, Piracicaba, Brasil. 2000. p. I35-I66.

BEWLEY, J. D.; BRADFORD, K. J.; HILHORST, H. W. M.; NONOGAKI, H. Seeds: Physiology of development, germination and dormancy, 3rd ed. Springer: New York, USA. 2013. 392p.

BRACHTVOGEL, E. L.; CONTRO MALAVASI, U. Volume do recipiente, adubação e sua forma de mistura ao substrato no crescimento inicial de Peltophorum dubium (Sprengel) Taubert em viveiro. Revista Árvore, v. 34, n. 2, p. 223 232, 2010.

BRASIL - Ministério da Agricultura, Pecuária e Abastecimento. Regras para análise de sementes. Mapa/ACS: Brasília, Brasil. 2009. 399p.

BRASIL. Lei $n^{\circ}$ I2.65 I, de 25 de maio de 20I2. Brasil. Código Florestal. Available at: http://www.planalto.gov.br/ ccivil_03/_ato20II-2014/2012/lei/II265I.htm. Accessed in: 25 Jun 2018.

CARVALHO, P.E. R. 2007. Cerejeira-da-Amazônia Amburana acreana. Available at: https://www.embrapa.br/florestas/buscade-publicacoes/- /publicacao/3/3872/cerejeira-da-amazonia--amburana-acreana. Accessed in: 12 Aug 2018.

DA SILVA, R. B. G.; SIMÕES, D.; SILVA, M. R. Qualidade de mudas clonais de Eucalyptus urophylla $\times E$. grandis em função do substrato. Revista Brasileira de Engenharia Agrícola e Ambiental, v. 16, n. 3, p. 297-302, 2012.

DICKSON, A.; LEAF, A. L.; HOSNER, J. F. Quality appraisal of white spruce and white pine seedling stock in nurseries. Forestry chronicle, v. 36, n. I, p. 10-13, 1960.

DONADON, J. R.; BESSA, J. F.; RESENDE, O.; CASTRO, C. F D. S.; ALVES, R.; SILVEIRA, E. V. Storage of crambe seeds in different containers and environments: Part II - Chemical quality. Revista Brasileira de Engenharia Agrícola e Ambiental, v. 19, n. 3, p. 231-237, 2015.
DUMROESE, R. K.; HEISKANEN, J.; ENGLUND, K.; TERVAHAUTA, A. Pelleted biochar: Chemical and physical properties show potential use as a substrate in container nurseries. Biomass and Bioenergy, v. 35, n. 5, p. 20182027, 2011 .

FIGUEIREDO, F. A. M. M.; CARNEIRO, J. G. A.; PENCHEL, R. M.; BARROSO, D. G.; DAHER, R. F. Efeito das variações biométricas de mudas clonais de eucalipto sobre o crescimento no campo. Revista Árvore, v. 35, n. I, p. I-I I, 20 I I.

GIRARDI, L. B.; BELLÉ, R. A.; LAZAROTTO, M.; MICHELON, S.; GIRARDI, B. A.; MUNIZ, M. F. B. Qualidade de sementes de cártamo colhidas em diferentes períodos de maturação. Revista Acadêmica: Ciência Animal, v. II, Supl. I, p. 67-73, 2017.

GOMES, J. M.; COUTO, L.; LEITE, H. G.; XAVIE, A.; GARCIA, S. L. R. Parâmetros morfológicos na avaliação da qualidade de mudas de Eucalyptus grandis. Revista Árvore, v. 26, n. 6, p. 655-664, 2002

GUNN, C. R. Seed topography in the Fabaceae. Seed science and technology, v. 9, p. $737-757,1981$.

KAPOOR, N.; ARYA, A.; SIDDIQUI, M. A.; KUMAR, H.; AMIR, A. Physiological and biochemical changes during seed deterioration in aged seeds of rice (Oryza sativa L.). American Journal of Plant Physiology, v. 6, n. I, p. 2835,2011 .

KRATZ, D.; WENDLING, I.; STUEPP, C. A.; FRAGOSO, R. O. Ranking of substrates based on the morphological parameters of the Piptadenia gonoacantha. Bosque, v. 37 , n. 2, p. 285-293, 2016.

MELLO, J. I. D. O.; FIGUEIREDO-RIBEIRO, R. D. C. L.; BARBEDO, C. J. Sub-zero temperature enables storage of seeds of Caesalpinia echinata Lam. Journal of Seed Science, v. 35, n. 4, p. 519-523, 2013.

MOTLAGH, Z. R.; SHABAN, M. Effect of seed ageing in on physiological traits in plants. Scientia Agriculturae, v. 6, n. 3, p. I26-129, 2014.

OLIVEIRA, O. S. Tecnologia de sementes florestais: espécies nativas. Editora da UFPR: Curitiba, Brasil. 2012. 404p.

PEZZUTTI, R. V.; CALDATO, S. L. Sobrevivência e crescimento inicial de mudas de Pinus taeda L. com diferentes diâmetros do colo. Ciência Florestal, v. 2I, n. 2, p. 355-362, 20 I I.

RIBEIRO, E. S.; DE SOUZA, R. A. T. M.; DE PAULA, M. H.; DE MESQUITA, R. R. S.; MOREIRA, E. L.; FAZION, H. Espécies florestais comercializadas pelo estado de mato grosso. Biodiversidade, v. I5, n. 2, p. I-20, 2016.

RIBEIRO-OLIVEIRA, J. P.; RANAL, M. A. Sementes florestais brasileiras: início precário, presente inebriante e o futuro, promissor? Ciência Florestal, v. 24, n. 3, p. 77I-784, 2014. 
SHABAN, M. Review on physiological aspects of seed deterioration. International Journal of Agriculture and Crop Sciences, v. 6, p. 627, 2013.

SOUZA, C. A. M.; OLIVEIRA, R. B.; MARTINS FILHO, S.; LIMA, J. S. Desenvolvimento em campo de espécies florestais em diferentes condições de adubação. Ciência Florestal, v. 16, n. 3, p. 243-249, 2006.

STUEPP, C. A.; WENDLING, I.; KOEHLER, H. S.; ZUFFELLATO-RIBAS, K. C. Quality of clonal plants of Piptocarpha angustifolia in different renewable substrates and seasons of the year. Pesquisa Agropecuária Brasileira, v. 5I, n. II, p. I82I-I829, 2016.

VENTURA, L.; DONÀ, M.; MACOVEI, A.; CARBONERA, D.; BUTTAFAVA, A.; MONDONI, A.; ROSSI, G.; BALESTRAZZI, A. Understanding the molecular pathways associated with seed vigor. Plant Physiology and Biochemistry, v. 60, p. 196-206, 2012.
VIJAY, K.; LOKESH, G. Y.; BASAVE, G.; PATIL, S. B.; GANIGER, B. S.; RAKESH, C. M. Accelerated ageing test to study the relative storage potential of hybrid sunflower-RSFH-I30 (Helianthus annuus). African Journal of Agricultural Research, v. 10, n. 35, p. 3502-3506, 2015.

WALTERS, C. Orthodoxy, recalcitrance and in-between: describing variation in seed storage characteristics using threshold responses to water loss. Planta, v. 242, n. 2, p. 397-406, 2015.

WIELEWICKI, A. P.; LEONHARDT, C.; SCHLINDWEIN, G.; MEDEIROS, A. C. S. Proposta de padrões de germinação e teor de água para sementes de algumas espécies florestais presentes na região sul do Brasil. Revista Brasileira de Sementes, v. 28, n. 3, p. 191-197, 2006.

ZUCHI, J.; FRANÇA-NETO, J. D. B.; SEDIYAMA, C. S.; LACERDA FILHO, A. F. D.; REIS, M. S. Physiological quality of dynamically cooled and stored soybean seeds. Journal of Seed Science, v. 35, n. 3, p. 353-360, 2013. 